\title{
石井章雄 学位論文審査要旨
}

$\begin{array}{cccc}\text { 主査 } & \text { 佐 } & \text { 藤 } & \text { 建 } \\ \text { 副主査 } & \text { 箸 } & \text { 本 } & \text { 英 } \\ \text { 吉 } \\ \text { 同 } & \text { 押 } & \text { 村 } & \text { 光 } \text { 雄 }\end{array}$

\section{主論文}

Telomere shortening with aging in the human pancreas

（ヒト膵臓の加齢に伴うテロメア長の短縮）

(著者：石井章雄、仲村賢一、岸本宏志、本間尚子、相田順子、沢辺元司、新井冨生、 藤原睦憲、竹内二士夫、加藤基伸、押村光雄、泉山七生貴、田久保海誉）

平成18年9月 Experimental Gerontology 41巻 882頁～886頁 


\section{学 位 論 文 要 旨}

\section{Telomere shortening with aging in the human pancreas （ヒト膵臓の加齢に伴うテロメア長の短縮）}

ヒト正常培養細胞は有限寿命であることがHayflickらによって見出されたが、この現象 は培養系における老化のモデルと考えられる。これは、染色体末端のテロメアが一定の長 さ以下になった結果細胞周期が停止するためである。テロメアはヒト線維芽細胞やリンパ 球では細胞分裂ごとに33-120 bp短縮することが報告されている。これまで全身の臟器・組 織あるいは培養細胞株のテロメア長が測定され、テロメア動態について報告がなされてい るが、膵蔵については未実施であり、世界的にも他研究室からの報告がない。本研究では、 ヒト膵臓のテロメア長について、サザンブロット法を用いて測定し、テロメア短縮動態に ついて考察した。またこれまでの臓器データとの比較検討を行った。

\section{方 法}

新生児16例、百寿者2例を含む0歳から100歳までの剖検72例（男性35、女性37）を対象と した。炎症、病変部位を除いた、正常なヒト膵臟頭部からSDS・プロテアーゼK法で可溶化 し、フェノールクロロフォルム法を用いてDNAを抽出した。ジェノフィールド電気泳動によ り未消化DNAのサイズを検討し、100 kbp以上のものを実験に用いた。DNA $5 \mu \mathrm{g}$ 制限酵素 で切断し、それぞれDNAが完全消化されたことを確認した後、サザンブロット法を行い、転

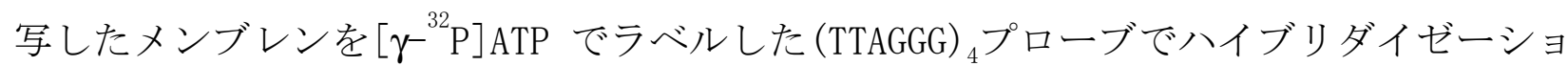
ンを行った。ついでBAS-2500Macを用いて画像を解析した。Terminal Restriction Fragment (TRF) シグナルのピーク值を同時に泳動したサイズマーカーの移動距離から算出してテロ メア長（modal value）とした。実験の再現性を検討するため、Hinf I及びRsaIを用いた テロメア長の測定值を比較した。平均值の差の検定にはStudent's $t$ test を、相関分析 にはFisherのZ検定を用いた。

\section{結 果 と 考 察}

未消化DNA72例のパルスフィールド電気泳動の結果は3例が100 kbp以下であり、この3例 を除いた69例を以後のテロメア長の測定に用いた。制限酵素Hinf I とRsaI で消化したテ ロメア長測定の結果は極めて類似し、よく再現されていた。 


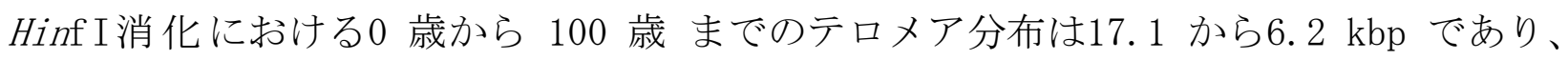
年間短縮率は36 bp $[\mathrm{Y}=13.709-0.036 \times$ 年龄（ $\mathrm{r}=-0.6068 、 \mathrm{p}<0.0001 ）]$ あった。 新生児16例のテロメア長の分布みてみると、17.1-12.1 kbp と生後直後においても幅があり、 個体特有の長さを持っていることが示唆された。

次に年間短縮率と細胞回転との関係について考察すると、ヒトではデータがないがマウ スの膵臓の腺房細胞の細胞更新に要する時間は70日と報告されている。一方、細胞回転時 間の速い胃腸粘膜上皮では約一週間、細胞更新の遅い腎臓、肝蔵では150～350日とされて いる。いままでに我々がテロメア長を測定したヒトの臓器・組織のデータは、表皮 (36 bp)、 舌上皮 $(30 \mathrm{bp})$ 、食道上皮（60 bp）、胃粘膜（47 bp）、大腸粘膜（59 bp）、腎皮質（46 $\mathrm{bp})$ 、肝組織（55 bp/60 bp）、脾臓（29 bp）、甲状腺（90 bp）、副甲状腺（94 bp）、 灰白質（有意減少無）心筋（有意減少無）であった。以上のデータは、細胞分裂停止した 細胞からなる大脳灰白質や心臓を除き、テロメアの年間短縮率はほぼ 100 bpの範囲に収ま っており、年間短縮率は必ずしも細胞回転の速度を直接には反映していないことが推測さ れる。

テロメア短縮の年齢変化についてFrenckらは、テロメアは生涯一定の割合で短縮するの でなく、若年で急激に減少しそれ以後プラトーの時期を経て老年になると穏やかに再度減 少すると報告している。今回のデータはこれを一部支持する結果となった。

Cawthonら（2003）はテロメア長と生存率を比較し、短いテロメア長を持つ個体は加齢に 伴う疾病に罹りやすく死亡率が高いと報告している。またテロメア長が個体毎に特有の長 さを持っていると考えると、膵臓のテロメアの長い個体は他の臓器組織も長いことが予想 された。テロメア長は病疾への罹患のしやすさと寿命を予知している可能性があり、今後 さらに研究すべき課題である。

\section{結 論}

これまで報告のなかったヒト膵臓におけるテロメア長を0から100歳までの剖検69例につ いて測定したところ、17.1 kbpから $6.2 \mathrm{kbp}$ 分布をもち、加齢に伴い減少すること、その 年間短縮率は36 bpであることが明らかになった。出生直後の新生児16例において既に 17.1 〜 12. $1 \mathrm{kbp}$ と幅があることから、個体には特有のテロメア長があることが示唆された。こ れらの知見は、膵臓疾患とテロメア長との関連を明らかにする上での重要な基礎データに なることが期待される。 